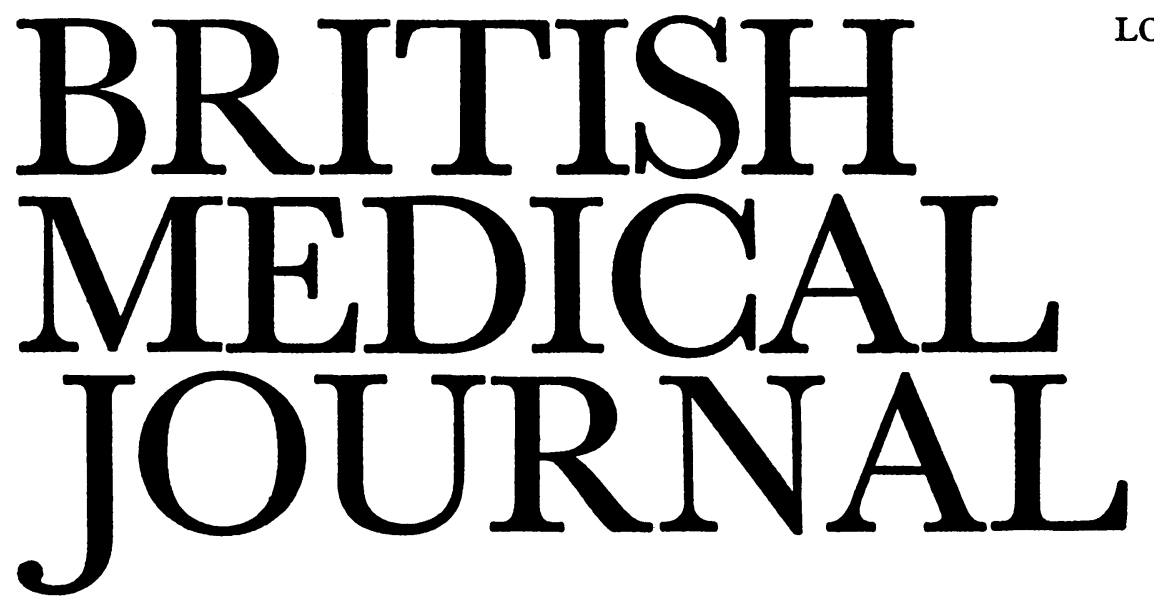

LONDON SATURDAY 29 SEPTEMBER 1973

\title{
The Point of the Lancet
}

With that earnest but slightly iconoclastic sense of mission that is one of its attractive features the Lancet first addressed itself to the medical profession aptly enough on a Sunday. Now 150 years later we salute this great journal and with a host of well-wishers look forward to another 150 years of instruction and entertainment from it.

When he founded the Lancet in 1823 Thomas Wakley saw it as a vehicle for reports of lectures delivered by the medical celebrities in London and for his radical views on social reform. As the lectures were mostly private and the lecturer charged a fee for attendance, the great men who delivered them were often incensed to read a pirated version in the new journal. Nor did Wakley's reforming zeal make for an easy life. But he found, as many others have, that to champion unpopular causes in language that was frequently intemperate even by the standards of his day can be as lucrative as it is vexing. The result was a flourishing journal. A historical sketch of the journal and its editors, by Professor W. H. McMenemey, appears by invitation in our middle pages this week.

Then as now both topical and readable, the Lancet set its standards from the first sentence. It begins the report of a lecture by Sir Astley Cooper in the surgical theatre at St. Thomas's Hospital only four days previously, a publishing feat that would be hard to emulate today in a periodical of that quality, and reads as follows: "At half-past Seven this Theatre was crowded in every part, by upwards of four hundred Students, of the most respectable description. . .." Nor is it only by the speed of its publication that this sentence commands the respectful astonishment of today's reader.

More lectures, correspondence, news from France, editorial polemics against a review in a rival journal followed in later issues-"we shall content ourselves on the present occasion with proving the Reviewer to be a consummate adept in the art of lying, and a wilful garbler and falsifier ..." and so on. The medicine and surgery of that day had not yet become encrusted in a jargon that makes the readers of some pages of the Lancet or B.M.F. in 1973 wonder whether it is the words or the cases they report that have been "randomized" by double-blind authors. We may admire, for instance, the clarity of this sentence: "During the eight days that he survived the operation, he complained of great pain in the bladder, but there was no tenderness of the abdomen." Can things really have been as simple as that? And if there are differences in the themes on which their writers discourse in the 1823 and the 1973 Lancets the two volumes have at least one thing in common, and that oddly enough is acupuncture, or "acupuncturation" as it was then called. "Much has lately been said of the efficacy of this remedy in various affections" we read in 1823,1 and "Interest in acupuncture has been aroused by reports in the Press and on television" we learn 150 years later. ${ }^{2}$ But it would be unfair to leave the impression that the Lancet, for all its piquancy, is centred on acupuncture. Many weightier matters have enlightened readers of its pages as much as delighted the authors who have been allowed to contribute to them.

As well as an individual character the Lancet has a unique status. It is the only general medical weekly that is not published by or on behalf of an association of doctors. Many people would say that to start such a journal today would be madness, yet the Lancet pioneered a formula that has inspired other journals and endured with evolutionary modification in its own. The heart of the matter is the conjunation of original papers with up-to-date comment and current news. It may be a bold assumption that doctors will accept between one pair of covers the results of specialized research and the products of its digestion in the form of explanatory articles, but as well as a successful history this formula continues to have a contemporary appeal.

The reports and lectures in the earliest volumes of the Lancet are as scrupulously detailed as those to be read today. They presuppose in their audience an attentive study of the subject and a wish to understand thoroughly the succession of signs and symptoms in an illness, the exact timing and dosage of treatment, and the precise technique of an operation. We read of a patient in Guy's Hospital, for instance, who on 19 January 1824, at 2 p.m., "Has just taken three pills, containing 15 grains of rhubarb: continues the effervescing mixture, and also takes some rose mixture (infusion of roses slightly acidulated), every three or four hours." Nothing slapdash about this with its note of the time and definition of the mixture. Moreover, if the Lancet's comments are now perforce less ferocious than they used to be, they nonetheless remain shanply pointed. For it has always appealed to men and (later) women with a serious interest in the practice of their profession. And it has given 
them a perpetual commentary on medical affairs that is at once humane and astringent, an infusion of roses slightly acidulated.

1 Lancet, 1823, 1, 200.

2 Mann, F., et al., Lancet, 1973, 2, 57.

\section{Sleep and Metabolism}

Food nourishes the body in a manner that depends on the internal hormonal environment, and evidence is rapidly gathering to link this process with sleep. It is the growing animal that sleeps the most, while even older people feel renewed by it.

In growing children growth hormone reaches its highest concentration in the plasma at night. ${ }^{1}$ This has been related specifically to periods of stage 4 deep sleep, a stage that occurs early in the night and shows the slowest and largest waves in the electroencephalogram (E.E.G.). Delaying sleep by eight hours was found to delay similarly the secretion of growth hormone, ${ }^{2}$ and deliberate disturbance of sleepers whenever the E.E.G. looked as if stage 4 was imminent prevented progression into stage 4 and inhibited the growth hormone response. $^{34}$ The response is independent of blood glucose ${ }^{4} 5$ and is not suppressed by amylobarbitone, ${ }^{6}$ but it can be prevented by artificially raising the concentration of free fatty acids in the plasma ${ }^{7}$ or by giving depot corticotrophin. ${ }^{8}$

Prolactin, traditionally related to lactation, reaches a high level during sleep in both young women and men. ${ }^{9}$ The rise is not due to an in-built rhythm, as had been supposed, ${ }^{10}$ but is dependent on sleep itself. ${ }^{11}$ Recently concentrations of luteinizing hormone, which before puberty and then in adult life are the same waking and sleeping, have been found to rise two to four times higher during sleep with the onset of puberty in boys and girls. The secretion of this hormone is not governed by light but by sleep, for delay of the sleep period will delay the secretion. ${ }^{12}$

In contrast plasma corticosteroids rise steeply towards the end of the night as a result not of sleep but of an in-built rhythm that is slow to change when sleeping habits alter. ${ }^{13}$ The low levels of corticosteroids early in the night suit the secretion of growth hormone that normally occurs then, for the growth hormone promotes synthesis of body protein, ${ }^{14}$ whereas high levels of corticosteroids inhibit this anabolic action in man. ${ }^{15}$ Prolactin seems to be broadly linked with anabolic processes, but until it becomes available in quantity its full actions in man will remain unknown. In general we may conclude that growth hormone, prolactin, and luteinizing hormone appear to link sleep with tissue development or repair.

Bodily growth can be stunted in adverse emotional environments, and a syndrome of psychosocial dwarfism is associated with poor sleep. G. Wolff and J. Money, of Baltimore, measured the growth rates of 27 such children at intervals over years. They assessed sleep from nurses' reports and similar records. Growth averaged $1 \mathrm{~cm}$ per month of good sleep but only one-third as much during periods of poor sleep. ${ }^{16}$ The authors suggest that the release of growth hormone may have been impaired during the poor sleep. They state (without detailed figures) that these children had low levels of growth hormone in the plasma and that these levels rose when conditions improved, as had earlier been reported. ${ }^{17}$ But C. F. Whitten and colleagues, of Detroit, had attributed the dwarfism of such children to poor feeding and found they could improve growth by sending special packages of food to the home while the child continued to live in the otherwise adverse environment. ${ }^{18}$ If children in these circumstances have a reversible deficiency of growth hormone, that would argue against semi-starvation as the cause of their dwarfism, because marasmic children, and adults with anorexia nervosa, have high resting levels of the hormone. ${ }^{19} 20$ This is apparently a compensatory device, since its actions in sparing protein and promoting its synthesis presumably help to preserve life.

Changes in body weight and food intake in adults also seem to be linked with sleep. It is an old observation that many depressed patients complain of early morning waking and loss of weight but that a few mention weight gain and good sleep. Lately A. H. Crisp and E. Stonehill ${ }^{21}$ have reported an investigation of 375 psychiatric outpatients. One interviewer assessed recent sleep and sleep before the illness, while another assessed present and previous weight. Subsequently a consultant rated specific psychiatric features. The findings showed that loss of weight was associated with recent decreased or broken sleep and gain in weight with increased sleep, and that these associations held true independently of mood, psychiatric diagnosis, or age. It was in the second half of the night especially that poorer sleep was associated with loss of weight and vice versa.

Animals kept short of food are more restless and sleep less than normal ${ }^{21}{ }^{23}$ and it seems reasonable that well-stocked reserves should be associated with less broken sleep at the end of the night. In a well-designed study back in $1937 \mathrm{~N}$. Kleitman and colleagues ${ }^{24}$ found sleep to be less restless after a bedtime malted milk drink, irrespective of whether it was made with milk, or water, and recently two studies ${ }^{25} 26$ on young adults and those in late middle age have shown that the second half of the night was less broken after a malted milk drink. It looks as if the role of sleep in the body's economy may soon be clearer.

1 Hunter, W. M., and Rigal, W. M., Acta Endocrinologica (Copenhagen), 1965, Suppl. 100, 121.

2 Sassin, J. F., et al., Science, 1969, 165, 513

3 Sassin, J. F., et al., Science, 1969, 165, 513.

4 Schnure, J. J., Raskin, P., and Lipman, R. L., fournal of Clinical Endocrinology and Metabolism, 1971, 33, 234.

${ }^{5}$ Parker, D. C., and Rossman, L. G., Fournal of Clinical Endocrinology and Metabolism, 1971, 32, 65.

6 Ogunremi, O. O., et al., British Medical fournal, 1973, 2, 202

Lipman, R. L., Taylor, A. L., Schenk, A., and Mintz, D. H., fournal of Clinical Endocrinology and Metabolism, 1972, 35, 592.

${ }^{8}$ Evans, J. I., Glass, D., Daly, J. R., and MacLean, A. W., fournal of Clinical Endocrinology and Metabolism, 1973, 36, 36.

- Sassin, J. F., Frantz, A. G., Weitzman, E. D., and Kapen, S., Science, $1972,177,1205$.

${ }^{10}$ Nokin, J., Vekemans, M., L'Hermite, M., and Robyn, C., British Medical Fournal, 1972, 3, 561 .

Sassin, J. F., Frantz, A. G., Kapen, S., and Weitzman, E. D., fournal of Clinical Endocrinology and Metabolism, 1973, in press.

12 Boyar, R., et al., New England fournal of Medicine, 1972, 287, 582. Weitzman, E. D., et al., Transactions of the American Neurological Association, 1968, 93, 153.

14 Korner, A., Recent Progress in Hormone Research, 1965, 21, 205.

Rudman, D., Freides, D., Patterson, J. H., and Gibbas, D. L., fournal of Clinical Investigation, 1973, 52, 912.

16 Wolff, G., and Money, J., Psychological Medicine, 1973, 3, 18.

17 Powell, G. F., Brasel, J. A., Raiti, S., and Blizzard, R. M., New England Fournal of Medicine, 1967, 276, 1279.

18 Whitten, C. F., Pettit, M. G., and Fischoff, J., fournal of the American Medical Association, 1969, 209, 1675.

19 Samuel, A. M., and Deshpande, U. R., fournal of Clinical Endocrinology and Metabolism, 1972, 35, 863.

${ }^{20}$ Marks, V., Howorth, N., and Greenwood, F. C., Nature (London), 1965, 208, 686 .

21 Crisp, A. H., and Stonehill, E., British Fournal of Psychiatry, 1973, 122,

${ }^{22}$ Hagamen, W. D., Archives of Neurology, 1959, 1, 203

${ }^{23}$ Jacobs, B. L., and McGinty, D. J., Experimental Neurology, 1971, 30,

212 .
24 Kleitman, N., Mullin, F. J., Cooperman, N. R., and Titelbaum, S., Sleep Characteristics. Chicago, University of Chicago Press, 1937.

${ }^{25}$ Southwell, P. R., Evans, C. R., and Hunt, J. N., British Medical fournal, $1972,2,429$.

26 Bŕezinová, V., and Oswald, I., British Medical fournal, 1972, 2, 431. 